\title{
The Popularization of Lianyungang Agriculture E-commerce Platforms and the Innovative Research Report under the Mode of Government and College Cooperation
}

\author{
Xiaowei $\mathrm{Ma}$ \\ Jiangsu vocational college in finance and accounting, Jiangsu, China \\ mlbsabc@sina.com
}

Keywords: Government and college cooperation; Agriculture informatization; Popularization of platform; Innovativeness; E-commerce

\begin{abstract}
Agriculture informatization is an important method to realize the agriculture modernization. This paper regards Lianyungang agriculture E-commerce platform as the research object as the research object. Directed by the mode of government and college cooperation, this paper takes the popularization of agriculture E-commerce platform as the research target, explores the innovativeness of the mode of government and college cooperation by using the resource advantage of local colleges and universities, further advance the fusion of talents, scientific research and agriculture in order to serve the local economy and form a new pattern of the "Internet + Agriculture".
\end{abstract}

\section{The Research Background}

At present, the informatization appears in rural areas, but the infrastructure in rural areas lags behind and the popularization rate of Internet is low, so the problem of information of "the last one kilometer" becomes a great obstacle for E-commerce in rural areas. In market economy, the need of agricultural products for information is urgent, so the information is especially important for the economy in rural areas and the income of farmers. The number of agricultural websites in China is definitely less, accounting for less than $5 \%$ of the total national websites. Due to the lack of specialized agriculture E-commerce service platform, the Information can not be collected and released in time. As a result, the application and popularization of computer communication and network technology lag behind. Every year, agricultural loss in Jiangsu caused by information asymmetry is huge. Farmers have great blindness and hysteresis in the decision of what to produce and how many to produce. So the production and sale are accompanied by risks.

At present, the personnel engaged in the work of agricultural information in our province can not meet the demands of the development of agricultural informationization in the aspect of knowledge structure, and their overall quality is low. First, we lack agricultural information technology professionals, so the personnel don't have high ability of development. Second, we lack information analysis personnel, which result in a large number of information resources can't get reasonably developed and applied. Third, the overall quality of basic information service personnel needs to be further improved.

\section{The Present Situation of the Development of the Agricultural Informationization in Lianyungang}

The Current status of Developments of Agriculture Informatization and Rural E-commerce in the City of Lianyungang. A batch of agriculture E-commerce model villages are built. By the end of 2105, Lianyungang city agriculture commission and Lianyungang city business bureau jointly identified 10 agriculture E-commerce model villages in Donghai county. Beigou village of Double store town of Donghai county and Haihou village of Haitou town of Ganyu area are voted " one village, one brand, one store" model villages in Jiangsu Province. More than four enterprises in Zhangdian village of Guannan county, Beigou village of Donghai county, Haihou village of Ganyu area and Qiaodang village of Guanyun county are approved as provincial agricultural E-commerce demonstration bases 
Agricultural Products Selling on Internet Has Become the Norm. We make full use of functions of products' exhibit and sell, transaction and talk over, order online, online payment and other functions of various E-commerce websites, such as Suning E-commerce, Taobao, Jingdong number one shop and Alibaba, actively guide the main market players of agricultural enterprises, farmers ' professional cooperative association and big-specialized-households of crop and animal productions to open the marketing store in e-commerce sites, in order to expand sales scope of agricultural products of high quality in Lianyungang. According to incomplete statistics, the total agricultural products selling on Internet in the year of 2015 is more than one billion Yuan.

Wechat Business of Agricultural Products Spring Up. Now, many Wechat business operations such as "Source of grapes", "The first fresh fruit orchards" and "fresh fruits bay" are in full swing. The E-commerce platform of " fresh fruits bay" of Ace preservation group has its own modern farm, professional research and development testing center, fresh cut factory and delivery team. Since its launch in July 2015, the online sales reaches more than 1 million yuan.

The Application Status of Agricultural Internet Technology Steadily Improves. Lianyungang city counties widespread applications of efficient facilities for fruits and vegetables, livestock and poultry breeding in large scale and standardized bases, on the basis of existing agricultural Internet of things technology's pilot project. The demonstration sites of new agricultural iot technology application reach 24.

Agricultural Information Service Development Is In Good Condition. We should give publicity to agricultural information network, electronic screen and publicity column internal, and actively contact newspapers, radio and television stations and other media platforms external. At the same time, in order to make full use of spread advantage of new media in line with the guiding ideology of "open and transparent, timely response, service for the people", we release more than 1000 pieces of agricultural technical guidance information in a timely manner through Lianyungang city agriculture official WeChat and weibo.

The Situation of System Construction of Agricultural Information Improves. Lianyungang city counties have set up special agricultural information services. The city counties are completely covered with constructions of rural information service stations. The four-level of agricultural information service overlay network-the city-level rural information center, county-level agriculture commission information center or business dept, the village-level and town-level agricultural service center and village-level agricultural information service point - has been built.

The Construction of Agricultural Information Platform of International Cooperation Demonstration Zone-"Belt and Road" is Planned in an Orderly Way. The information platform is a comprehensive application system which combine the needs of agricultural managements and agricultural information services of "Belt and Road" Lianyungang international cooperation demonstration zone, and design with information collection, distribution, processing, storage, development and application for the integration, provide decision support tools for agricultural decision-making departments, management departments, trade associations, ordinary farmers and agricultural resources management and relevant institutions in the demonstration area, and offer a full range of agricultural information service for the society.

\section{The Problems Existing in the Developments of Agriculture Informatization and Rural E-commerce in Lianyungang City}

The first is the countryside E-commerce starts late and the overall development of E-commerce in Lianyungang city is relatively slow. So their support to rural E-commerce development is small. Besides, most of the rural enterprises, rural cooperatives habitually use the traditional way of selling products and have not enough understanding of new E-commerce. The second problem is that logistics and information technology popularization are still in initial development stage. Logistics and information foundation work relatively lag behind and cannot satisfy the existing development needs. The third is agricultural output is less, and there are many sorts of fresh agricultural products which is more difficult in collecting, packaging, transportation and preservation. Due to the particularity of online transactions, 
there are little products suitable for online selling. The fourth problem is the lack of professional talents. The agricultural information engineering is a new project and the overall quality of rural E-commerce service personnel is not high, they can not master the modern information technology such as computer well. Very few people understand technology and can also operate and maintain technology while people who understand and can operate and maintain technology rarely want to service rural places, which leads to the lack of rural E-commerce professionals.

To solve above problems, the information platform set up by Lianyungang city agriculture committee will solve many problems existing in the development processes of agriculture informatization in Lianyungang city and E-commerce. But there is a long way to go in aspects of platform popularization and talents training. Therefore, led by the government, Lianyungang city agriculture committee signed government and college cooperation framework agreements with Jiangsu vocational college in finance and accounting, which builds up a bridge between the government and university and college, and opens up a new model of "government and college cooperation" for Lianyungang agriculture informatization under the background of "Internet + agriculture".

\section{The Lianyungang Agricultural Electronic Informatization Platform Popularization and Innovative Research under the Mode of "Government and College Cooperation"}

Innovative measures of the Lianyungang Agriculture Informatization Platform Popularization. The Lianyungang agricultural information platform can be taken as platform for training students' professional skills. In the oepned courses such as "Network marketing" and "Search engine optimization (SEO)", students take Lianyungang agriculture informatization platform as the real training places. By using combination of various kinds of network marketing tools effectively, students' practical abilities are improved and some website visits are brought for promotion of the platform in the early stage. By following up the Lianyungang local influential BBS and answering posts to make hype, the influence of Lianyungang agriculture informatization platform on the local networks has been greatly improved. During the daily maintenance of platform, Lianyungang agriculture informatization platform web page can be updated on time and sites can be debugged by learning the course of "website construction and maintenance" which can effectively save the Lianyungang city agriculture commission's human and financial resources for maintaining the platform and can improve work efficiency. Students can effectively transfer the knowledge of the agriculture informatization and new mode of E-commerce back to the countryside and serve the local economy through practical operation of agricultural information platform. Jiangsu accounting vocational college students are mainly from local place, and quite a number of the students are from countryside. Students use course training and word of mouth effect, bring the modern production and marketing docking mode of government's lead and enterprises' participate, and the functions and service aim of agriculture informatization platform to their hometown, greatly improve the breadth and depth of modern agricultural development in Lianyungang. Take the E-commerce major of the school for example, during the learning of the "online entrepreneurship" courses, students are required to set up shops online as the main way of training. By using online recommended online store columns on the agriculture informatization platform, students can link the websites of Taobao, Jingdong and group-purchase to the system so that customers can enter the enterprise' shops in Taobao, Jingdong and group-purchase websites directly through this system, which can promote the agricultural E-commerce development and production and marketing docking.

Agricultural E-commerce training should be vigorously promoted through government and college cooperation. According to the requirements of Lianyungang city agricultural E-commerce training, E-commerce training modules in agriculture informatization platform can publish notices such as online agricultural training courses and class time. Enterprises and farmers can submit personal information for online registration after seeing the notices, then agriculture commission will publish notice and organize offline E-commerce training if the registration quantity reaches a certain number (eg. 30 people). Through the way of "register online and offline training", the awareness of agricultural E-commerce was raised and development of agricultural E-commerce was promoted. The course was opened on the basis of new professional farmers job skills, combining with the current development situation of modern 
agriculture in Lianyungang city. It formed practical teaching resources integrated by professional teachers, relied on the agricultural technology and the practical training bases constructed by E-commerce professional basic course, professional core courses and professional development courses of Jiangsu vocational college in finance and accounting. It formed "skills - module -- project" triple module, agricultural information technology module and agricultural management module. Every three modules of "basic skills training, production training and the comprehensive optimum post training" are composed of $3 \sim 5$ courses. By setting up the commodity photography ", "network marketing" and other related courses, the college provides E-commerce required technical skills to rural farmers. The college also promotes projects such as transformation of scientific and technological achievements by participating in rural participation subject research and provides related technology consulting services, and effectively accelerate agricultural production and operation E-commerce in Lianyungang.

To Build a Long-term Mechanism of Innovative Research under the Pattern of "Government and College Cooperation". Under the pattern of "government and college cooperation", the cooperation between Lianyungang city agriculture committee and Jiangsu vocational college in finance and accounting have established close and effective comprehensive cooperative relations. In the future, both sides should increase the intensity of fusion in talents cultivation, scientific research and the professional construction. They shall actively create conditions, establish a long-term mechanism and form a long-term, stable comprehensive cooperative relations between government and university and college in order to promote the harmonious developmen of school teaching and research and mutual local economy and society.

Establish an innovation mechanism of "discuss and decide together, linkage synergy together" and long-act government and university and college. In terms of operating mechanism construction, it should build operation mode based on "discuss and decide together, linkage synergy together" in order to make the participated departments and personnel as an organic coordination whole and continuously run with high quality and efficiency under the right decisions.

One thing is the major affairs of cohesion and consultation. As the major lead of the mode of government and college cooperation, government should give full play of its lead function and improve law protection system. The government's maintaining cohesion and consultations with the college on important matters can give full play to the advantages and functions of government and college, further effectively integrate resources and make college's technology advantage and talent advantage dock and interact with regional resource advantage.

Two is communication and negotiation in important fields. Important areas and important scientific research concerning local economic and social development are government's main work and also is the direction of college's discipline construction, professional development and personnel training. Through communication and consultation in the field of important areas, government can make the best of academic and talent advantages, cooperate in multifaceted way to improve the independent innovation capacity of local place, speed up economic restructuring and accelerate the transformation and upgrading of industry. At the same time, in view of key areas of the regional economic and social development, colleges and universities can make clear their own school-running orientation and service orientation to establish the goal of the core of subject construction and development of colleges and universities.

Three is docking and consulting of key projects. The docking and consulting of key projects are research institutions organized by college and government. Secondary school enterprises and government departments clear their respective responsibilities and rights and obligations by form of docking and consulting surrounding the implementation of projects. The docking and consulting of key projects can promote the high quality resources integration of regional colleges and governments, improve the effect of government and college and university cooperation, thus provide power for the sustainable development of local economy and society. 


\section{Perfect the Management System and Standard and Safeguard Effective Development of Mechanism Innovation}

To innovate the operating mechanism of government and college cooperation, the key is to improve the operation of the organization, operation procedure and management system. From the perspective of market economy, the establishment of operation mechanism innovation needs to set up a set of mature and standardized process and method. Only by turning innovation into organized group activities can ensure innovation running in a steady manner.

So the basic requirements of the operational mechanism innovation of "discuss and decide together, linkage synergy together" of government and college cooperation is to establish a standardized program and make government and college cooperation in a regular, orderly and efficient way.

First, to improve the operation organization based on contract. Establish a government and college cooperation contract. The goal of "win-win" is the guarantee of government and college cooperation. The rights and obligations of both sides formed by the contract are the premise of establishing government and college cooperation running organization.

Second, to form running processes based on a scientific way. The essence of running mode of government and college cooperation is in accordance with requirements of "discuss and decide together, linkage synergy together" . Manners include: Governments and colleges and universities put forward the problem to be solved in view of the regional social and economic development and the orientation and development goals of colleges and universities; The government and college cooperation organizations establish ways and methods to solve the problems according to the technology, talents and financial resources of governments and universities; The secondary colleges and industry enterprises which belong to the research institutions implemented by university and government undertake the specific duty to solve the problems; Governments and universities and colleges distribute the cooperation interests according to the agreement to achieve the maximization of economic and social benefits of government and college cooperation.

Third is to improve the operation management system based on specifications. By constructing the running system, we should give full play to the functions of "constraint, coordination, command,incentive and orientation" of the system. The working mechanism of "discuss and decide together, linkage synergy together" requires the government and college cooperation organizations to pay attention to build the system of "consult and discuss for great events, linkage for urgent things". These systems have certain binding for governments and universities and colleges and affiliated research institutions, enterprises and individuals, which can ensure the process of cooperative operation in an orderly way and clear work objectives.

\section{Reference}

[1] Liu, J.C. (2013) discuss and decide together, linkage synergy together: Explore on running mechanism innovation of government and college cooperation, Jiangsu higher education, (1), 66-67.

[2] Li, Y.Q. (2016) Analysis on the construction of new think-tank in new normal horizon, Jiamusi vocational college journal, (11),168.

[3] Li, Y.Q. (2015) Research on the long-term and profound cooperation in the mode of government and university and college linkage, Contemporary Vocational Education, (11), 21-23.

[4] Lei, W.S., Wu,J.H. And Yan, Z.M.(2014) Research and exploration on cultivating new professional farmers under the government and college cooperation, Vocational and Technical Education Forum,(30), 59-62.

[5] Wu, J.H. (2014) Exploration on education mode of higher vocational school's entrepreneurship under the background of government and college cooperation, Reading and writing,(8), 52-53. 
[6] Yang, Y. and Li, X.H. (2014) Japan's Developing Experiences in E-Commerce Logistics and the Inspiration on China. China Business and Market, 28, 34-39.

[7] Guo, K. and He, M.K. (2015) Study on Preference of Self-developed or Third Party Logistics of E-commerce Retail Enterprises. Logistics Technology, 34, 126-129.

[8] Dai, J., Jia, Q. and Wang, J. (2014) Study on Influence Factors of Customer Satisfaction in Logistics Distribution Services under B2C E-commerce Environment. Logistics Technology, 9, 166-170.

[9] Dai, F.F. (2014) Listed on the Impact of Small and Medium-Sized Enterprise Financing Structure on Corporate Performance Empirical Research. Beijing Jiaotong University, Beijing.

[10]Zhang, P.F. (2015) The Empirical Study of Relationship between Structure and Operating Performance of Corporate Financing. Shanghai Academy of Social Sciences, Shanghai. 